\title{
EVALUASI PENGUNGKAPAN AKUNTANSI LINGKUNGAN DALAM PERSPEKTIF PT TIMAH (PERSERO) TBK
}

\author{
Rosinta Ria Panggabean; Holly Deviarti \\ Accounting Department, Faculty of Economic and Communication, BINUS University \\ Jln. K.H. Syahdan No 9, Kemanggisan-Palmerah, Jakarta 11480 \\ Rosinta_Ria_Panggabean@binus.ac.id; Bunda_mustafa@binus.ac.id
}

\begin{abstract}
Timah is the pride of the province of Bangka Belitung and its society, despite the presence of Timah mining directly harmful to the environment such as forests and water pollution. Nevertheless, PT Timah is very popular with environmental preservation activities and empowering the local community. The purpose of this study is to evaluate environment preservation associated with financial reporting. The issue of Green Accounting will be very interesting if it is supported by qualitative data as evidence. Using the descriptive method, and data retrieval literature and interviews with community of Bangka Belitung, it can be concluded that PT Timah has good action up the environment. The results of this study will enhance a good image for PT Timah.
\end{abstract}

Keywords: timah, green, accounting, mining, preserved environment

\begin{abstract}
ABSTRAK
Timah merupakan kebanggaan provinsi Bangka Belitung dan masyarakatnya, meskipun kehadiran pertambangan timah secara langsung berbahaya bagi lingkungan seperti hutan dan polusi air. Akan tetapi, PT Timah sangat populer dengan kegiatan pelestarian lingkungan dan pemberdayaan masyarakat setempat. Tujuan dari penelitian ini adalah untuk mengevaluasi pelestarian lingkungan terkait dengan pelaporan keuangan. Masalah akuntansi lingkungan akan sangat menarik jika didukung oleh data kualitatif sebagai bukti. Dengan menggunakan metode deskriptif, dan pengambilan data dan wawancara dengan masyarakat Bangka Belitung menyimpulkan bahwa PT Timah memiliki tindakan yang baik atas lingkungan. Hasil dari penelitian ini akan meningkatkan citra yang baik bagi PT Timah.
\end{abstract}

Kata kunci: timah, akuntansi, lingkungan, pertambangan, pengendalian lingkungan 


\section{PENDAHULUAN}

Keadaan teknologi pada kehidupan manusia memengaruhi keseimbangan lingkungan hidup yang berada di sekitar manusia. Kapitalisme yang dipelopori oleh Amerika Utara awalnya memberi pandangan bahwa manusia tidak perlu menghitung biaya terhadap air, tanah, udara dan sumber daya alam lain karena manusia memilikinya dalam jumlah yang sangat besar. Manusia hanya perlu menghitung transaksi jual-beli semata (Rubenstein (1989), dalam Halim \& Irawan, 1998).

Perserikatan Bangsa-Bangsa (PBB) pada tahun 1992 mengadakan Konferensi Lingkungan dan Pembangunan atau Earth Summit di Rio de Janeiro, dihadiri oleh lebih dari 178 pemerintah, untuk membahas pembangunan yang berkelanjutan. Dalam konferensi tersebut semakin besar kesadaran akan isu lingkungan dalam peningkatan kesejahteraan pada masa mendatang. Agenda 21 PBB merekomendasikan agar negara-negara menerapkan akuntansi lingkungan (INTOSAI Working Group on Environmental Auditing, 2010).

Ketua Ikatan Akuntan Indonesia Kompartemen Akuntan Manajemen (IAI-KAM) sekaligus Direktur Eksekutif National Center for Sustainability Reporting (NCSR) Ali Darwin, Ak, MSc, dalam artikel majalah Akuntan Indonesia Edisi No.3 November 2007, melihat ada empat hal alasan isu lingkungan semakin signifikan. Pertama, ukuran perusahaan yang semakin besar. Semakin besar perusahaan, diperlukan akuntabilitas yang lebih tinggi dalam pembuatan keputusan berkaitan dengan operasi, produk dan jasa yang dihasilkan. Kedua, aktivis dan LSM bidang lingkungan hidup telah tumbuh dengan pesat di seluruh dunia termasuk Indonesia. Mereka akan mengungkap sisi negatif perusahaan yang terkait dengan isu lingkungan hidup dan akan menuntut tanggung jawab atas kerusakan lingkungan atau dampak sosial yang timbul oleh operasi perusahaan. Ketiga, reputasi dan citra perusahaan. Perusahaan-perusahaan saat ini menyadari bahwa reputasi, merek, dan citra perusahaan merupakan isu strategis bernilai tinggi dan harus dilindungi. Keempat, perkembangan teknologi komunikasi yang sangat cepat. Isu lingkungan dan sosial yang berdampak negatif akan menyebar dan dapat diakses dengan mudahnya menggunakan teknologi informasi.

PT Timah (Persero) Tbk (“PT Timah”) adalah perusahaan pertambangan timah di Indonesia yang terletak di propinsi Bangka Belitung. Sebagai produsen timah kedua terbesar di dunia, PT Timah telah mengoperasikan kegiatan penambangan timah yang terintegrasi mulai dari eksplorasi, penambangan, peleburan hingga pemasaran produk ke luar negeri. Sebagai perusahaan pertambangan besar, maka sudah sepatutnya PT Timah memerhatikan lingkungan serta kondisi kehidupan masyarakat sekitar akibat dari kegiatan pertambangannya. Dengan latar belakang tersebut, penulis melaksanakan penelitian Akuntansi Lingkungan dalam perspektif PT Timah (Persero) Tbk. Berdasarkan latar belakang di atas, maka dapat diidentifikasikan masalah-masalah terkait dengan Akuntansi Lingkungan. Masalah-masalah itu antara lain: seperti apa keterkaitan pelaporan keuangan PT Timah dengan pemeliharaan lingkungan, kegiatan yang dilaksanakan PT Timah dalam pemeliharaan lingkungan, dan seperti apa keterkaitan antara tindakan pemeliharaan lingkungan dengan citra perusahaan di masyarakat. Dari ketiga identifikasi masalah tersebut, maka tujuan penelitian ini adalah untuk mendeskripsikan evaluasi laporan keuangan terkait dengan tanggung jawab sosial yaitu pemeliharaan lingkungan dari sisi akuntansi dan tindakan nyata yang dilakukan oleh PT Timah dalam pemeliharaan lingkungan serta citra masyarakat sebagai umpan balik atas kegiatan yang dilakukan oleh PT Timah dari aspek manajerial.

Menurut Environmental Accounting Guidelines (2005:3), akuntansi lingkungan mencakup pengidentifikasian biaya dan manfaat dari aktivitas konservasi lingkungan, penyediaan sarana atau cara terbaik melalui pengukuran kuantitatif, untuk mendukung proses komunikasi agar mencapai pembangunan yang berkelanjutan, memelihara hubungan menguntungkan dengan komunitas serta meraih efektivitas dan efisiensi dari aktivitas konservasi lingkungan. Pengertian dari US EPA (1995) melihat akuntansi lingkungan sebagai aspek akuntansi manajemen, mendukung keputusan manajer 
bisnis mencakup penentuan biaya, keputusan desain produk atau proses, evaluasi kinerja serta keputusan bisnis lainnya.

Fungsi akuntansi lingkungan terbagi menjadi dua, yaitu internal dan eksternal (Environmental Accounting Guidelines, Japan, 2005). Fungsi internal memungkinkan perusahaan untuk mengatur biaya konservasi lingkungan dan menganalisis biaya lingkungan dengan manfaatnya, serta meningkatkan efektivitas dan efisiensi aktivitas konservasi lingkungan terkait dengan keputusan yang dibuat. Melalui pengungkapan hasil pengukuran kuantitatif dari kegiatan konservasi lingkungan, fungsi eksternal memungkinkan sebuah perusahaan untuk memengaruhi keputusan stakeholder, seperti konsumen, mitra bisnis, investor, dan masyarakat lokal. Publikasi dari akuntansi lingkungan diharapkan dapat memenuhi tanggung jawab perusahaan dalam akuntabilitas stakeholder dan digunakan untuk evaluasi dari konservasi lingkungan.

United States Environmental Protection Agency (US EPA) menyebutkan jika biaya-biaya yang terjadi di perusahaan dapat terbagi menjadi beberapa kelompok:

\section{Conventional Costs}

Conventional Costs merupakan biaya menggunakan bahan baku, utilitas, barang modal, dan pasokan yang umumnya dibahas dalam akuntansi biaya dan penganggaran, namun tidak dipertimbangkan sebagai biaya lingkungan. Penurunan penggunaan serta berkurangnya limbah yang dihasilkan dari bahan baku, utilitas, barang modal, dan pasokan yang ramah lingkungan dapat mengurangi degradasi lingkungan dan penggunaan dari sumber daya yang tidak dapat diperbarui.

\section{Potentially Hidden Costs}

Potentially Hidden Costs adalah biaya-biaya yang berpotensi tersembunyi dari manajer, di antaranya upfront environmental costs, yang terjadi sebelum proses operasi. Biaya ini mencakup biaya perancangan produk ramah lingkungan, kualifikasi pemasok, evaluasi peralatan pengendalian pencemaran alternatif, dan lain-lain.

\section{Contingent Costs}

Contingent Costs adalah biaya yang mungkin terjadi atau tidak terjadi pada masa depan. Misalnya, biaya kompensasi atas kecelakaan pencemaran lingkungan, denda dan hukuman pelanggaran peraturan masa depan, atau biaya tak terduga lainnya atas konsekuensi masa depan.

\section{Image and Relationship Costs}

Image and Relationship Costs dikeluarkan untuk memengaruhi persepsi manajemen, pelanggan, karyawan, masyarakat, dan regulator. Biaya ini juga dapat disebut sebagai biaya "citra perusahaan”. Biaya kategori ini dapat termasuk biaya pelaporan lingkungan tahunan dan kegiatan hubungan masyarakat, biaya yang dikeluarkan sukarela untuk kegiatan lingkungan seperti menanam pohon, dan biaya yang dikeluarkan untuk program penghargaan atau pengakuan.

Di Indonesia, UU No.40 Tahun 2007 pasal 74 mengatur bahwa perseroan yang menjalankan kegiatan usaha di bidang dan/atau berkaitan dengan sumber daya alam wajib melaksanakan Tanggung Jawab Sosial dan Lingkungan. Tanggung Jawab Sosial dan Lingkungan tersebut merupakan kewajiban perseroan yang dianggarkan dan diperhitungkan sebagai biaya perseroan yang pelaksanaannya dilakukan dengan memerhatikan kepatutan dan kewajarannya. Apabila kewajiban ini tidak dilaksanakan, maka dikenai sanksi sesuai dengan ketentuan peraturan perundang-undangan. Ketentuan lebih lanjut mengenai Tanggung Jawab Sosial dan Lingkungan diatur dengan peraturan pemerintah. 
Pelaksanaan Tanggung Jawab Sosial dan Lingkungan biasanya dicatatkan dalam suatu laporan yang dapat dilaporkan secara terpisah maupun digabung dalam laporan tahunan. Pelaporan Tanggung Jawab Sosial dan Lingkungan di Indonesia diatur oleh IAI (Ikatan Akuntan Indonesia) yang menyarankan kepada perusahaan untuk mengungkapkan tanggung jawab mengenai sosial dan lingkungan sebagaimana tertulis pada Standar Akuntansi Keuangan (PSAK) no 1 (Revisi 2009) paragraf 12 berbunyi:

Entitas dapat pula menyajikan, terpisah dari laporan keuangan, laporan mengenai lingkungan hidup dan laporan nilai tambah (value added statement), khususnya bagi industri dimana faktor lingkungan hidup memegang peranan penting dan bagi industri yang menganggap karyawan sebagai kelompok pengguna laporan yang memegang peranan penting. Laporan tambahan tersebut di luar lingkup Standar Akuntansi Keuangan.

Dari sisi standar akuntansi, Dewan Standar Akuntansi Keuangan (DSAK IAI) memutuskan untuk merevisi PSAK 33 (1994): Akuntansi Pertambangan Umum dalam rangka proses konvergensi IFRS di Indonesia. PSAK 33 (1994): Akuntansi Pertambangan Umum direvisi menjadi PSAK 33 (revisi 2011): Aktivitas Pengupasan Lapisan Tanah Dan Pengelolaan Lingkungan Hidup Pada Pertambangan Umum. Ruang lingkup PSAK 33 (revisi 2011): Aktivitas Pengupasan Lapisan Tanah Dan Pengelolaan Lingkungan Hidup Pada Pertambangan Umum diantaranya mengatur perlakuan akuntansi atas Aktivitas Pengelolaan Lingkungan Hidup. Provisi pengelolaan lingkungan hidup harus diakui jika terdapat petunjuk yang kuat bahwa telah timbul kewajiban pada tanggal pelaporan keuangan akibat kegiatan yang telah dilakukan, dan terdapat dasar yang wajar untuk menghitung jumlah kewajiban yang timbul.

Taksiran biaya untuk pengelolaan lingkungan hidup yang timbul sebagai akibat kegiatan eksplorasi dan pengembangan diakui sebagai aset (beban tangguhan). Taksiran biaya untuk pengelolaan lingkungan hidup yang timbul sebagai akibat kegiatan produksi tambang diakui sebagai beban. Pada tanggal pelaporan, jumlah provisi pengelolaan lingkungan hidup harus dievaluasi kembali untuk menentukan apakah jumlah akrualnya telah memadai. Jika jumlah pengeluaran pengelolaan lingkungan hidup yang sesungguhnya terjadi pada tahun berjalan sehubungan dengan kegiatan periode lalu lebih besar daripada jumlah aktual yang telah dibentuk, maka selisihnya dibebankan ke periode di mana kelebihan tersebut timbul.

Global Reporting Initiative (GRI), merupakan panduan pelaporan perusahaan untuk mendukung pembangunan berkelanjutan yang digagas oleh PBB lewat Coalition for Environmental Economies (CERES) dan UNEP pada tahun 1997. GRI merupakan organisasi non-profit yang mempromosikan keberlanjutan sosial, ekonomi dan lingkungan. GRI menyediakan kerangka pelaporan keberlanjutan yang komprehensif bagi semua perusahaan dan organisasi yang banyak digunakan diseluruh dunia. Pedoman pengungkapan GRI terdiri dari G3, G3.1 dan G4. G3 atau yang sering dikenal dengan G 3.0 merupakan versi awal dari pedoman GRI yang terdiri dari 79 indikator dan merupakan pedoman yang sering digunakan sampai saat ini. G3.1 merupakan versi pengembangan dari G3 yang didalamnya terkandung 84 indikator termasuk 79 indikator yang digunakan sebelumya pada G3 dengan beberapa perubahan dan tambahan-tambahan lainnya yang dinilai lebih menyempurnakan pedoman GRI.

Belum banyak penelitian yang dilakukan untuk membahas masalah akuntansi lingkungan, berikut akan dibahas beberapa penelitian terdahulu. Mihardika (2012) dalam penelitiannya menjelaskan bahwa rencana IAI mengadopsi IFRS membuat pelaku industri di Indonesia harus menyesuaikan kebijakan akuntansinya terhadap PSAK yang terbaru. Di kuartal 32011 PSAK 33 (1994) tentang Pertambangan Umum mengalami revisi karena adanya adopsi IFRS 6: "Exploration for and Evaluation of Mineral Resources”. Hasil adopsi IFRS 6 tersebut berakibat PSAK 33 (1994) dipecah menjadi 2 PSAK, yaitu PSAK 33 (revisi 2011): Aktivitas Pengupasan Lapisan Tanah Dan Pengelolaan Lingkungan Hidup Pada Pertambangan Umum dan PSAK 64 (2011): Aktivitas 
Eksplorasi dan Evaluasi Pada Pertambangan Sumber Daya Mineral. Tujuan dari penelitian Mihardika ialah untuk memperoleh gambaran dan pemahaman yang lebih mendalam mengenai dampak perubahan PSAK 33 (1994), sehingga dapat memahami kondisi yang diperlukan dalam penerapan standar akuntansi tersebut di sebuah perusahaan. Dan sampel dari penelitian ini adalah laporan keuangan PT. Antam (Persero) Tbk. dari sebelum adanya perubahan PSAK tersebut hingga masa peralihan dengan standar yang baru. Hasil penelitian ini dapat disimpulkan bahwa perubahaan PSAK 33 (1994) tidak berdampak cukup signifikan pada angka-angka di laporan keuangan namun dari sisi kebijakan yang diterapkan di perusahaan mengalami perubahan.

Sahasrakirana (2012) dalam penelitiannya menyebutkan bahwa aspek lingkungan menjadi suatu hal yang sensitif, dimana hal tersebut dapat memberikan pengaruh signifikan terhadap keberlanjutan perusahaan. Penelitian yang dilakukan bertujuan untuk mengetahui aktivitas apa yang membutuhkan peranan akuntansi lingkungan, bagaimana gambaran penerapan akuntansi lingkungan serta apakah informasi akuntansi lingkungan dapat memengaruhi keputusan manajemen lingkungan. Objek penelitian adalah PT Sahabat Mewah dan Makmur yang memproduksi minyak kelapa sawit mentah atau Crude Palm Oil (CPO). Metode penelitian yang digunakan adalah dengan cara wawancara dan observasi langsung terhadap objek penelitian. Hasil penelitian menunjukkan bahwa perusahaan belum mengungkapkan informasi lingkungan secara detail, belum ada konversi dari data lingkungan menjadi data ekonomi, serta belum adanya akuntan yang terlibat dalam aktivitas lingkungan.

Santy (2012) menyoroti penambangan batubara yang dapat mengakibatkan berbagai kerusakan kelestarian alam dan kesehatan masyarakat sekitar pertambangan. Tanggung jawab sosial perusahaan atau Corporate Social Responsibility adalah bahwa organisasi khususnya (namun tidak hanya) perusahaan memiliki suatu tanggung jawab kepada stakeholder dalam berbagai aspek operasional perusahaan mulai dari pelanggan, pemasok, klien, pemegang saham, karyawan, media, masyarakat, hingga pemerintah dan lingkungan. Cara pengukuran kinerja CSR dilakukan dengan menggunakan standar-standar pengukuran pelaporan Global Reporting Initiative GRI 3.1 dalam indikator-indikatornya. Penelitian Santy bertujuan untuk mengungkap kinerja pelaporan CSR oleh perusahaan pertambangan batubara di Indonesia dan Australia dengan menggunakan metode content analysis. Dengan mengumpulkan data-data dari sampel penelitian, kemudian diperhitungkan jumlahjumlah pengungkapan berdasarkan indikator-indikator GRI 3.1 dan diolah dengan skala Likert sehingga menghasilkan suatu informasi baru yang berguna. Hasil penelitian menemukan bahwa sebagian besar perusahaan pertambangan batubara di Indonesia dan Australia belum melaksanakan CSR-nya dengan baik berdasarkan jumlah pengungkapan CSR-nya yang kebanyakan belum memenuhi separuh dari indikator GRI.

\section{METODE PENELITIAN}

Data yang diperlukan untuk penelitian ini diambil dari laporan tahunan PT Timah (Persero) Tbk tahun 2009, 2010 dan 2011. Untuk tahun 2009 ditambah dengan laporan khusus pengelolaan lingkungan yang terpisah. Jenis laporan ini untuk tahun 2010 dan 2011 sudah digabungkan dalam laporan tahunan. Metode analisis data yang digunakan dalam penelitian ini menggunakan metode content analysis. Metode ini digunakan untuk mengukur informasi mengenai akuntansi lingkungan pada data yang dikumpulkan dengan mengacu pada indikator utama tentang lingkungan G3.1 GRI sebagai berikut.

Indikator Kinerja Lingkungan (environment performance indicator), mencakup: sub-indikator material, meliputi penggunaan bahan serta bahan yang berasal dari daur ulang; sub-indikator energi, indikator energi meliputi lima area penting dari penggunaan energi suatu organisasi, termasuk energi langsung dan tidak langsung. Energi langsung adalah energi yang digunakan oleh organisasi dan 
produknya serta jasanya. Penggunaan energi tidak langsung adalah energi yang digunakan oleh organisasi atau komunitas lain yang melayani organisasi; sub-indikator air, penjelasan mengenai penggunaan air, sumber air yang terpengaruh kegiatan perusahaan; sub-indikator biodiversitas (keanekaragaman hayati), penjelasan mengenai lokasi yang bersinggungan dengan daerah yang dilindungi serta berbagai dampak kegiatan perusahaan terhadap keanekaragaman hayati; sub-indikator emisi, efluen dan limbah meliputi indikator yang mengukur pengeluaran standar terhadap lingkungan yang dipertimbangkan sebagai polutan; sub-indikator produk dan jasa, mencakup inisiatif perusahaan dalam mengurangi dampak lingkungan dalam produk dan jasanya; sub-indikator kepatuhan, pengungkapan nilai moneter denda dan sanksi terkait regulasi lingkungan; sub-indikator pengangkutan/transportasi, pengungkapan dampak lingkungan akibat pemindahan produk dan barang lainnya; sub-indikator menyeluruh yang mengungkapkan jumlah pengeluaran untuk proteksi dan investasi lingkungan menurut jenisnya. Sedangkan daftar sub-indikator selengkapnya dapat dilihat pada Lampiran Tabel 2.

Metode penyajian data yang digunakan adalah metode statistik deskriptif, yaitu statistik yang digunakan untuk menganalisis data dengan cara mendeskripsikan atau menggambarkan data yang telah terkumpul sebagaimana adanya tanpa bermaksud membuat kesimpulan yang berlaku umum (Sugiyono, 2008).

\section{HASIL DAN PEMBAHASAN}

Kerusakan lingkungan di Bangka Belitung akibat aktivitas penambangan kurun beberapa tahun ini memasuki tahap mengkhawatirkan. Terutama di daerah-daerah yang potensial dengan galian timah. Pertambangan juga mengakibatkan pencemaran, merusak sumber air, daerah aliran sungai (DAS) mengalami pendangkalan, bahkan ada sungai dan sumber air yang hilang. Masalah ini ditujukan kepada PT Timah dan para penambang liar, kerusakan alam akibat penggalian Timah dapat membahayakan masyarakat sekitar. Undang-Undang Nomor 04 tahun 2009 tentang Mineral dan Batu Bara, peluang masyarakat di Bangka Belitung terbuka. Kemudahan memperoleh izin usaha pertambangan bagi para pelaku tambang dari pemegang kekuasaan (bupati/walikota, gubernur hingga level menteri ESDM). Hal tersebut mengakibatkan banyaknya penambangan liar yang dilakukan tanpa mempertimbangkan pemeliharaan lingkungan. Berdasarkan satelit tahun 2004, diketahui bahwa 378.042 hektar dari 657.510 hektar kawasan hutan di Bangka Belitung sudah tergolong lahan kritis.

Dalam rangka pemeliharaan lingkungan PT Timah mengupayakan kegiatan Corporate Social Responsibility (CSR) yang berkesinambungan, perusahaan telah mengalokasikan sebagian dananya khusus untuk aktivitas-aktivitas sosial tersebut. Perusahaan menyiapkan anggaran pada tahun 2009, sekitar Rp 26,6 miliar untuk pelaksanaan program CSR yang merupakan dana yang wajib dicadangkan bagi perusahaan yang memanfaatkan sumber daya alam (SDA). Dari segi pemberdayaan lingkungan dan bentuk pertanggungjawaban perusahaan untuk memulihkan fungsi lahan yang telah digunakan untuk pertambangan sebelumnya. Maka, Perusahaan juga telah melakukan pencadangan biaya rehabilitasi lingkungan sesuai dengan Undang-undang No.4/1982 tentang Ketentuan Pokok Pengelolaan Lingkungan Hidup dan diimplementasikan dalam Surat Keputusan Direksi Perusahaan No.001/B/SK-0000192-B1 tanggal 02 Januari 1992 dan diperbaharui dengan Surat Keputusan Direksi No.167/SK-0000197-B tanggal 16 Juli 1997. Besarnya saldo dana biaya rehabilitasi yang dicadangkan oleh Perusahaan pada akhir tahun 2009 adalah sebesar Rp 120,65 miliar. Pembiayaan dari segi Program kemitraan yang ditujukan pada pengembangan sektor pembangunan ekonomi masyarakat dicadangkan melalui Program Kemitraan Bina Lingkungan (PKBL) yang dananya merupakan alokasi pembagian laba perusahaan. Dana program kemitraan tersebut disalurkan kepada mitra binaan Perusahaan dan koperasi. Pada tahun 2009 jumlah dana yang telah dialokasikan dan bergulir untuk Program Kemitraan adalah sebesar Rp 16,41 miliar dan yang terealisasi atau tersalurkan adalah sebesar Rp 13,76 miliar untuk 933 mitra binaan Pencadangan dana untuk Program Bina Lingkungan pada tahun 2009 adalah sebesar Rp 5,94 miliar, dan yang tersalurkan adalah sebesar Rp 2,38 miliar. 
Dana tersebut disalurkan oleh Perusahaan untuk kepentingan sosial masyarakat di sekitar lingkungan wilayah operasi pertambangan dalam hal pendidikan, pelatihan, kesehatan, dan sebagainya.

PT Timah telah melakukan kegiatan sosial dari tahun ke tahun dan akan terus dilakukan untuk tahun ke depan. Rencana kerja untuk Program Kemitraan pada tahun 2010 mencakup alokasi penyaluran dana pinjaman sebesar Rp 11,2 miliar yang akan disalurkan dalam 2 semester. Perusahaan juga merencanakan untuk melakukan pemantauan yang bertugas untuk mengevaluasi perkembangan usaha Mitra Binaan dalam kelancaran memenuhi kewajibannya. Perusahaan juga melakukan penyaluran dana pinjaman, pelatihan kewirausahaan, promosi mitra binaan, korespondensi Mitra Binaan. Dalam segi Bina Lingkungan, Perusahaan merencanakan alokasi sebagian dananya yang akan digunakan untuk program pendidikan, pelatihan, kesehatan, sarana dan prasarana umum, pembinaan masyarakat, dan juga bantuan bencana alam bagi masyarakat yang memerlukan. Untuk bantuan pendidikan, Perusahaan menargetkan untuk menyelenggarakan pendidikan Polman (Politeknik Manufaktur), SMA unggulan, dan juga pelatihan ketrampilan yang minimal akan diikuti 400 orang. Rencana tersebut akan dilaksanakan sepanjang tahun 2010. Bantuan sarana dan prasarana umum yang telah direncanakan oleh Perusahaan untuk tahun 2010 adalah membangun 150 unit rumah layak huni di daerah yang memerlukan. Perusahaan menargetkan untuk membangun 30 unit per dua bulannya. Pembangunan aliran listrik di desa-desa dengan menggunakan solar cell juga telah direncanakan untuk dijalankan pada tahun mendatang. Selain itu, Perusahaan juga merencanakan atas pembangunan pos kesehatan di kabupaten dan desa sekitar. Untuk mencanangkan kegiatan penghijauan, Perusahaan juga telah mengambil langkah yang untuk menjaga kelestarian lingkungan pasca pertambangan. Sepanjang tahun 2010 - 2012, Perusahaan merencanakan reklamasi seluas 2.000 ha per tahun selama 2 tahun mendatang.

Pelaksanaan reklamasi tersebut akan melibatkan sub kontraktor dan masyarakat setempat sebagai penyedia bibit. Kegiatan ini dilakukan demi kelangsungan hidup masyarakat dan lingkungan sekitar. Dengan adanya keikutsertaan masyarakat dalam kegiatan sosial ini, Perusahaan dapat menjalin kebersamaan hubungan antara perusahaan dan masyarakat demi kesejahteraan bersama dan seluruh pemangku kepentingan. Peran PT Timah dalam membantu keberdayaan lingkungan hidup sekitar dengan cara menanamkan 500.000 pohon setiap tahun di lahan bekas tambang. Dengan ini, Perusahaan berharap bahwa lahan bekas tambang dapat berfungsi sebagaimana mestinya kembali, dan berguna bagi masyarakat sekitar. PT Timah juga telah melaksanakan sosial report dalam menginformasikan Program Bina Lingkungan dalam majalah Stannia edisi bulanan.

Persetujuan dari Pemerintah telah diterima pada tahun 1993 atas tiga laporan mengenai lingkungan yaitu Studi Evaluasi Lingkungan (SEL), Rencana Pengelolaan Lingkungan (RKL), dan Rencana Pemantauan Lingkungan (RPL) yang diajukan oleh Perusahaan pada tahun 1992. Laporanlaporan tersebut memberikan informasi dan rencana pendahuluan kepada Pemerintah mengenai program-program pelestarian lingkungan pertambangan yang akan dilaksanakan oleh Perusahaan saat ini. Bagi masyarakat, keberadaan PT Timah adalah suatu kebanggaan karena Timah adalah perusahaan penambangan besar di provinsi tersebut, terlebih lagi para pejabat PT Timah adalah dari masyarakat setempat. Penyisihan biaya untuk pelestarian lingkungan terkait sekali dengan citra PT Timah yang cukup baik. Walaupun PT Timah tidak sepopuler tahun 1960-an dimana pada periode tersebut PT Timah sedang mengalami kejayaannya, tapi hal tersebut tidak menurunkan citra masyarakat setempat bahwa PT timah adalah bagian dari kehidupan mereka.

\section{Evaluasi Pengungkapan Akuntansi Lingkungan Berdasarkan GRI 3.1}

Sub-indikator Material; Perusahaan telah mengungkapkan sesuai dengan EN 1 perincian penggunaan bahan berdasarkan berat atau volume untuk tahun 2009, 2010 dan 2011. Demikian pula dengan pencantuman persentase penggunaan bahan daur ulang sesuai EN2 diungkapkan untuk tahun 2009, 2010 dan 2011. Sebagaimana ditunjukkan pada tabel 3 lampiran, material daur ulang yang Perusahaan gunakan dalam proses produksi logam timah di pabrik-pabrik peleburan Perusahaan 
adalah terak, debu, dross, hardhead, dan timah besi. Jumlah material daur ulang yang Perusahaan gunakan di tahun 2011 adalah 55.344 metrik ton (mton) atau mencakup 44\% dari total material untuk produksi. Jumlah ini mengalami penurunan baik dari segi kuantitas maupun persentase tahun 2010, yaitu masing-masing sebesar 72.085 mton atau 49\% dari total material. Penurunan sebesar $12 \%$ dari jumlah total material yang digunakan dalam proses produksi pada tahun 2011 menunjukkan peningkatan efisiensi proses peleburan di fasilitas peleburan PT Timah, mengingat produksi logam timah Perusahaan tahun 2011 hanya mengalami penurunan 6\% dari tahun 2010. Jumlah tahun 2010 juga stabil dari sisi persentase sama dengan tahun 2009, yaitu 49\% dari total material. Penurunan sebesar 7,1\% dari jumlah total material yang digunakan dalam proses produksi pada tahun 2010 karena produksi mengalami penurunan 10\% dari tahun 2009.

Sub-indikator Energi; Perusahaan telah mencantumkan penggunaan energi langsung dari sumber daya energi primer sesuai ketentuan EN3 untuk tahun 2009, 2010, dan 2011 yang dapat dilihat pada tabel 2 lampiran. Bahan bakar fosil merupakan sumber energi alam yang tak terbarukan yang paling banyak digunakan dalam kegiatan operasional PT Timah (Persero) Tbk. Hal ini berdampak langsung lingkungan, seiring membuat cadangan bahan bakar fosil di bumi semakin menipis dan meningkatkan konsentrasi gas rumah kaca akibat pembakaran. Oleh karena itu, tak dapat dipungkiri bahwa kegiatan usaha PT Timah berkontribusi terhadap akselerasi proses perubahan iklim global. Sumber energi yang digunakan dalam kegiatan proses produksi Perusahaan di tahun 2009, 2010 dan 2011 adalah solar industri atau high-speed diesel (HSD) dan minyak bakar. Perusahaan juga menggunakan batubara antrasit sebagai katalis dalam proses peleburan bijih timah.

Perusahaan juga telah mengungkapkan ketentuan EN4 untuk tahun 2009, 2010 dan 2011. Sepanjang tahun 2011, fasilitas PLTD di Unit Metalurgi menghasilkan energi listrik sebesar 15.651.416 kWh, atau setara dengan 56.345 GJ. Produksi listrik berkurang sebesar 2,2\% dari total 15.991.182 kWh, atau setara dengan 57,568 GJ di tahun 2010. Sebanyak 15.559.094 kWh atau 99,4\% dari total energi listrik tersebut digunakan untuk operasional Perusahaan, sedangkan sisanya untuk penggunaan pihak-pihak lain. Fasilitas PLTD Perusahaan turut memasok listrik pada sejumlah fasilitas publik di Pulau Bangka, Pulau Belitung, dan Pulau Kundur, mengingat sangat terbatasnya pasokan listrik dari Pemerintah di ketiga wilayah tersebut. Kendati sebagian besar kebutuhan listrik Perusahaan dipasok PLTD yang menggunakan bahan bakar solar, Perusahaan juga menggunakan energi tak langsung dalam bentuk listrik dari pihak luar untuk kebutuhan operasionalnya, baik di Kantor Pusat maupun di lokasi lainnya. Hingga akhir tahun 2011, PT Timah mengeluarkan biaya senilai Rp 1,4 miliar untuk pembayaran listrik dari Perusahaan Listrik Negara (PLN) yang dikonsumsi oleh seluruh unit usahanya. Jumlah ini mengalami peningkatan 32\% dibandingkan besaran tahun 2010 senilai Rp 1,1 miliar.

Pengungkapan EN5 mengenai penghematan energi menyatakan efisiensi dan efektivitas merupakan salah satu kunci penting dalam kinerja produksi Perusahaan, dimana hal ini diharapkan dapat menghemat penggunaan energi dan berdampak positif bagi pelestarian lingkungan. Oleh karena itu, Perusahaan terus melanjutkan sejumlah langkah inovatif pada fasilitas produksi Perusahaan, seperti pembangunan tambang besar dengan metodologi kerja yang lebih efisien, serta ekstensifikasi operasional KIP untuk menggantikan peran KK yang boros energi. Konsumsi listrik di tahun 2010 menurun sebesar 8,9\% dari total konsumsi 17,537,100 kWh tahun 2009. Akan tetapi, tidak disebutkan jumlah moneter penghematan tersebut.

Dalam pengungkapan untuk EN6 perusahaan menyatakan bahwa dalam upaya Perusahaan untuk mengembangkan teknik-teknik pemanfaatan energi terbarukan dalam proses produksi di Perusahaan, telah diidentifikasi tiga jenis bahan bakar terbarukan yang siap guna sebagai bahan bakar alternatif dari minyak solar. Ketiga bahan bakar tersebut adalah olein dan sterin yang berbahan dasar minyak sawit, dan minyak jarak. Bahan bakar alternatif dapat digunakan untuk menggerakkan mesinmesin di kapal keruk, kapal isap produksi, dan juga kapal lainnya. Sepanjang tahun 2011, Perusahaan masih melakukan kajian teknis dan kajian usaha sebelum melakukan alih teknologi bahan bakar secara 
komprehensif pada berbagai alat produksi utamanya. Hal ini telah disebutkan pula pada laporan tahunan sebelumnya. Dengan demikian realisasi inisiatif mendapatkan produk dan jasa berbasis energi efisien belum diwujudkan secara nyata oleh perusahaan.

Untuk menghemat konsumsi energi di seluruh unit Perusahaan, sejumlah upaya telah dilakukan secara kontinu sepanjang tahun 2011, termasuk penggunaan sistem komunikasi dan transfer data melalui jaringan untuk meminimalkan kebutuhan perjalanan dinas karyawan. Perusahaan juga mulai menjalankan sistem e-procurement untuk pengadaan barang dan jasa. Di tahun 2012, Perusahaan akan mulai memanfaatkan teknologi videokonferensi untuk semakin memudahkan komunikasi antara fasilitas-fasilitas produksi yang tersebar di berbagai tempat dan Kantor Pusat serta Kantor Perwakilan Jakarta. Video konferensi juga akan sangat mengurangi jumlah perjalanan dinas, dan pada akhirnya mengoptimalkan proses pengambilan keputusan. Di tahun 2010 perusahaan melengkapi setiap jajaran manajemen dengan telepon seluler untuk mempermudah pengambilan keputusan tanpa terhalang tempat dan waktu. Pengungkapan EN7 ini belum disertai dengan angka riil pengurangan konsumsi energi yang dicapai tahun 2009, 2010 dan 2011.

Sub-indikator Air; untuk pengungkapan mengenai EN8, EN9 dan EN10 adalah sebagai berikut. Pemanfaatan air dilakukan secara efisien dan bijaksana dalam setiap proses produksi di PT Timah. Dalam proses penambangan timah, baik di darat maupun lepas pantai, air digunakan untuk menyemprot lapisan tanah yang mengandung bijih timah, dan untuk memisahkan bijih timah dari material lainnya. Dalam proses peleburan bijih, air digunakan untuk mencuci bijih dan mendinginkan mesin-mesin dan generator. Perusahaan memperoleh sebagian besar air dari pembendungan aliran sungai di lokasi-lokasi penambangan. Sebagian kecil berasal dari air tanah dan laut yang telah diolah terlebih dahulu. Sepanjang tahun 2011, penggunaan air dicatat secara lengkap oleh Unit metalurgi, sementara pada unit-unit yang lainnya sifat pencatatannya tidak lengkap. Di tahun 2011, Unit Metalurgi menggunakan air dengan volume total 594.700 meter kubik (kiloliter), yang seluruhnya diperoleh dari waduk. Jumlah ini meningkat 18\% dari pemakaian air tahun 2010, yaitu 502.784 kiloliter. Sebanyak 262.528 kiloliter (44\%) digunakan untuk sarana produksi, sedangkan sisanya untuk keperluan lain, seperti di kompleks perumahan Unit Metalurgi. Penggunaan air oleh sarana produksi di tahun 2011 naik 28\% dari 205.851 kiloliter di tahun 2010. Penggunaan air keseluruhan di tahun 2010 turun 11\% dari penggunaan sebesar 566.123 kiloliter di tahun 2009.

Mengingat sumber air di sekitar Perusahaan jumlahnya banyak dan tidak terkonsentrasi di satu titik, maka tidak ada sumber air yang lebih dari 5\% volumenya digunakan untuk kebutuhan operasional Perusahaan. Perusahaan memastikan semua sumber airnya bukan sumber air yang sensitif ataupun berpotensi mengganggu kestabilan lingkungan atau populasi spesies tertentu. Maka dari itu, pengambilan air dari sumber-sumber tersebut oleh Perusahaan tidak berdampak signifikan terhadap penurunan volume air yang tersedia bagi masyarakat di sekitar ataupun dalam jangka panjang. Sumber-sumber air Perusahaan juga tidak pernah mengalami gangguan yang menyebabkan ekosistem sekitarnya kehilangan fungsi aslinya. Sepanjang periode pelaporan Perusahaan tidak pernah menerima keluhan ataupun pengaduan terkait ketersediaan dan kualitas air dari masyarakat dan Pemerintah.

Salah satu cara pelestarian lingkungan yang diupayakan oleh Perusahaan adalah penggunaan air secara efisien. Perusahaan memanfaatkan kembali sebagian atau bahkan seluruh air yang telah digunakan sebelumnya pada proses-proses produksi dan penambangannya. Sepanjang tahun 2011, air yang digunakan di seluruh tambang darat Perusahaan didaur ulang 100\% melalui penerapan sistem sirkulasi air tertutup. Perusahaan telah memperoleh izin dari Pemerintah Daerah untuk membendung air ke dalam waduk dan mengalirkannya ke lokasi penambangan dan unit-unit produksi melalui paritparit berukuran besar. Air ini digunakan berulang kali setelah melewati proses pengendapan lumpur dan material lainnya, serta disirkulasikan secara tertutup. Penambahan air baru hanya dilakukan jika volume air dalam sistem sirkulasi tertutup lebih rendah dari ambang batas yang telah ditentukan. Untuk pengungkapan EN10 ini perusahaan tidak mengungkapkan persentase dan total volume air yang digunakan kembali dan didaur ulang sepanjang tahun 2009, 2010 dan 2011. 
Sub-indikator Biodiversitas (Keanekaragaman Hayati); sekitar 8\% atau 27 ribu hektar dari luas wilayah IUP darat Perusahaan yang berupa hutan adalah daerah yang dikategorikan sebagai hutan lindung, dan sebanyak 1\% atau 2.648 hektar lainnya merupakan hutan konservasi. Hingga tahun 2011, pada kedua zona tersebut sama sekali tidak diadakan kegiatan penambangan darat oleh PT Timah. Semua kegiatan penambangan berlangsung di lokasi yang tidak bersinggungan dengan kawasan yang dikategorikan sebagai hutan lindung ataupun daerah dengan nilai keanekaragaman hayati yang tinggi di luar kawasan hutan lindung. Perusahaan tidak mengungkapkan secara detail ketentuan EN11 di tahun 2011, hanya ada di laporan tahun 2009 dan 2010 seperti dapat dilihat pada tabel 2 lampiran.

Kegiatan operasional Perusahaan senantiasa disertai dengan tanggung jawab untuk menjaga kondisi alam sekitarnya. Sepanjang tahun 2011, dilaporkan tidak ada satupun kegiatan Perusahaan yang berdampak signifikan terhadap keberagaman lingkungan. Cukup luas daerah hutan di Provinsi Bangka Belitung, termasuk yang terdapat di wilayah IUP Perusahaan namun tidak tersentuh kegiatan penambangan, merupakan hamparan tanah kosong atau padang rumput, jauh dari kondisi ideal untuk hutan yang seharusnya sarat keberagaman hayati. Dengan demikian pengungkapan EN12 tidak menyebutkan dampak signifikan terhadap keanekaragaman hayati. Terkait dengan pengungkapan EN13, menyadari bahwa kegiatan penambangan berpotensi menghadirkan dampak negatif bagi lingkungan, Perusahaan berusaha semaksimal mungkin untuk mencegah terjadinya dampak-dampak tersebut, dan memitigasinya apabila dampak tersebut tak terelakkan. Perusahaan sangat memerhatikan batas-batas daerah operasionalnya untuk memastikan bahwa tidak ada sedikitpun zona hutan lindung yang dimanfaatkan sebagai daerah produksi. Berbagai upaya pengelolaan lahan tambang agar dapat digunakan untuk jangka panjang dilaksanakan oleh Perusahaan, salah satunya dengan cara mereklamasi lahan pascatambang dalam WIUP Perusahaan. Ini dilakukan dalam rangka sedapat mungkin mengembalikan kondisi habitat dan keanekaragaman hayati wilayah tersebut ke kondisi aslinya. Selain untuk memenuhi kewajiban peraturan perundangan, reklamasi juga dirancang agar menghadirkan manfaat sosial ekonomi dan pengembangan masyarakat sekitar. Kegiatan reklamasi lahan pascatambang dilaksanakan secara terpadu oleh unit kerja K3LH dan CSR PT Timah Tbk, dan berlangsung dalam 4 tahapan.

Dalam proses reklamasi lahan pascatambang, Perusahaan melibatkan masyarakat sekitar dan mitra usaha sehingga dampak langsung dari kegiatan ini bagi kehidupan mereka dapat langsung dirasakan. Sementara itu, di tahun 2011 Perusahaan telah menyelesaikan tahap perataan atas lahan pascatambang Perusahaan seluas 121.381 ha. Sementara itu, lahan seluas 550,6 ha sedang dalam tahap penanaman (vegetasi), lebih sedikit daripada sasaran dalam RKAP 2011 seluas 1.400 ha. Kendala utama yang dijumpai dalam proses reklamasi lahan pascatambang adalah terbukanya akses kepada masyarakat untuk melakukan penambangan liar, sehingga kegiatan tersebut semakin menjadi-jadi. Bahkan banyak juga pihak yang justru menambang di daerah yang telah direklamasi oleh Perusahaan, menyebabkan terjadinya perubahan pola pengaturan lahan. Untuk menghindari konflik dengan masyarakat setempat terkait klaim kepemilikan tanah yang ditambang secara liar ataupun yang dilarang oleh mereka untuk direklamasi, Perusahaan selalu meminta pernyataan tertulis dari pihakpihak yang terkait dan yang berwenang, yang menyatakan bahwa mereka secara terangterangan menolak lahan tersebut direklamasi. Hingga tahun 2011, kegiatan restorasi lahan pascatambang yang dilakukan sejak 1992 telah berhasil melakukan perataan lahan seluas 8.000 ha, termasuk revegetasi pada sebagian area tersebut. Dengan selesainya proses pemulihan pada lahan-lahan pascatambang tersebut, maka integritas hutan sebagai habitat alami dapat kembali terwujud. Pada gilirannya, kestabilan lingkungan sekitar dan sumber-sumber daya terbarukan yang ada juga akan terpelihara.

Mengenai EN14 tentang strategi, tindakan dan rencana pengelolaan dampak terhadap keanekaragaman hayati adalah sbb. Komitmen PT Timah untuk menjaga keselarasan proses produksi dengan lingkungan yang lestari mendasari kegiatan penambangannya di darat dan laut. Seluruh kegiatan penambangan darat yang dilakukan Perusahaan di Kepulauan Bangka Belitung berlangsung di atas lahan yang disahkan oleh Pemerintah dengan terbitnya Izin Usaha Pertambangan (IUP). Hingga tahun 2011, Peraturan Menteri Kehutanan No. P.60/Menhut-II/2009 tentang Pedoman Penilaian 
Keberhasilan Reklamasi Hutan tetap menjadi salah satu landasan penyusunan strategi, aksi, dan rencana reklamasi di daerah operasional Perusahaan. Berbagai program kerja dilaksanakan sebagai perwujudan nyata komitmen Perusahaan untuk mengurangi dampak negatif dari kegiatan penambangan. Salah satu upaya komprehensif Perusahaan di tahun 2011 adalah persiapan pengembangan Stannia Ecopark di Desa Riding Panjang, Kecamatan Merawang, Kabupaten Bangka. Pembangunan Stannia Ecopark ditandai dengan penandatanganan Naskah Kesepakatan Bersama (NKB) dan peletakan batu pertama oleh Direktur Utama Perusahaan pada tanggal 14 Desember 2011. Perusahaan berencana untuk melanjutkan pembangunan Stannia Ecopark di tahun 2012 melalui beberapa tahapan pengembangan.

PT Timah (Persero) Tbk patuh pada berbagai aturan dan undang-undang yang mengelola berbagai aspek dalam kegiatan penambangan, termasuk pada International Union for the Conservation of Nature (IUCN), lembaga internasional yang berfokus pada pelestarian spesies dan sumber daya alam. Berdasarkan pandangan IUCN, kegiatan operasional perusahaan apapun sepatutnya tidak boleh mengganggu pelestarian lingkungan dan alam, apalagi menyebabkan spesies tertentu mengalami kepunahan. Di wilayah IUP Perusahaan, baik di darat maupun di laut, terdapat beberapa spesies atau kelompok makhluk hidup yang dilindungi, sehingga masuk ke dalam Daftar Merah (Red List) IUCN seperti dapat dilihat pada tabel 4 lampiran, yang juga merupakan pengungkapan untuk EN15. Perusahaan menjalankan kebijakan untuk tidak melakukan penambangan lepas pantai di daerah di mana terdapat konsentrasi terumbu karang, yang merupakan penunjang utama dari ekosistem laut. Upaya alih teknologi dari KK ke BWD yang sedang ditempuh Perusahaan juga memampukan Perusahaan untuk menambang di kedalaman hingga 60 meter. Dengan demikian, praktik penambangan Perusahaan menjadi lebih tidak mengganggu karena dapat dilakukan pada jarak yang cukup jauh dari pantai.

Sub-indikator Emisi, Efluen dan Limbah; PT Timah sebagai sebuah perusahaan yang begerak di bidang pertambangan turut berkontribusi pada jumlah dan konsentrasi gas rumah kaca di atmosfer. Hal inilah yang membuat Perusahaan berupaya semaksimal mungkin untuk mereduksi jumlah emisi di proses produksinya yang diharapkan akan berguna untuk kelangsungan mahluk hidup selanjutnya. Fasilitas untuk mengukur jejak karbon (carbon footprint) tahun 2011 masih belum diadopsi Perusahaan. Meskipun demikian, Perusahaan sedang menjalani proses persiapan untuk mulai melakukan pengukuran tersebut. Hingga saat ini, Perusahaan telah memantau kualitas udara secara kontinu, dan hasilnya tersaji dalam bentuk laporan tersendiri. Berbagai operasi Perusahaan secara langsung mengeluarkan gas-gas rumah kaca, terutama CO2 atau karbon dioksida, yang merupakan hasil dari proses pembangkitan listrik tenaga diesel, pembakaran, dan operasi mesin-mesin di daerah pertambangan. Pada tahun 2011, Perusahaan masih belum sepenuhnya mengimplementasikan program pengukuran atau penghitungan emisi CO2 di Perusahaan, sehingga pada akhir periode pelaporan, Perusahaan belum dapat melaporkan nilainya. Perusahaan berharap untuk dapat menerapkan program penghitungan jejak karbon secara menyeluruh di tahun 2012. Dengan demikian tidak dapat diungkapkan EN16 mengenai rincian jumlah emisi gas rumah kaca berdasarkan berat untuk tahun 2009, 2010, 2011.

Beberapa kegiatan operasional Perusahaan dalam skala yang jauh lebih kecil seperti penggunaan alat transportasi di darat dan laut, perjalanan dinas, serta operasional di beberapa kantor Perusahaan telah berkontribusi terhadap jumlah total emisi gas rumah kaca Perusahaan. Hingga akhir periode pelaporan, Perusahaan belum menghitung jumlah total emisi gas rumah kaca dari kegiatan yang besifat minor ini. Perusahaan mendukung program Pemerintah untuk mengurangi emisi gas rumah kaca sebagai bagian dari strategi mitigasi perubahan iklim dan pemanasan global. Langkahlangkah spesifik PT Timah dalam membantu mengatasi isu perubahan iklim dan pemanasan global ini antara lain adalah menanam pohon sebagai bentuk dukungan terhadap program Green Babel yang dicanangkan Pemerintah Provinsi Bangka Belitung. Namun, tidak ada pengungkapan jelas mengenai inisiatif pengurangan emisi gas rumah kaca dengan hasil pencapaiannya di tahun 2009, 2010, dan 2011. 
Industri pertambangan timah jelas menggunakan bahan-bahan kimia tertentu yang dapat menghasilkan gasgas terhalogenasi (gas yang mengandung atom-atom unsur halogen, yakni klorin dan bromine) walaupun dalam skala yang relatif jauh lebih kecil. Gas tersebut, khususnya klorofluoro karbon atau CFC sangat aktif peranannya dalam perusakan lapisan ozon yang melindungi mahluk hidup dari radiasi sinar matahari. Hingga akhir periode pelaporan, Perusahaan belum menghitung total emisi gas-gas penipis lapisan ozon dan mengidentifikasi sumber-sumber utama dari emisi gas-gas tersebut di lingkungan kerja. Dengan demikian, tidak dapat mengungkapkan ketentuan EN19 mengenai Emisi bahan kimia yang merusak lapisan ozon (ozone-depletig substances/ODS) yang diperinci berdasarkan berat untuk tahun 2009, 2010 dan 2011.

Proses yang terjadi saat peleburan bijih timah yang terjadi di Unit Metalurgi Kundur, Tambang Barat dan PLTD di Mentok, Kundur, Baturusa, dan Balaikarya Sungailiat menghasilkan emisi gas yang digolongkan sebagai nitrogen oksida (NOX) dan sulfur oksida (SOX). Sebagai polutan di udara, gas nitrogen oksida dan sulfur oksida dapat mengganggu mahluk hidup dengan memicu terjadinya hujan asam, menurunkan kualitas udara, memperparah degradasi hutan, dan menimbulkan beragam persoalan kesehatan lainnya. Sebagai langkah untuk menurunkan emisi gas-gas tersebut ke udara, Perusahaan telah lama menerapkan teknologi fuel gas desulphurization dilengkapi sarana baghouse filter, yang mampu menurunkan total emisi gas sulfur dioksida (SO2) dari cerobong asap hingga $80 \%$. Selain menjaga keberlangsungan mahluk hidup, dengan berbagai tindakan ini, Perusahaan juga mendapatkan keuntungan finansial karena penerapan kedua teknologi tersebut menghasilkan kondisi cerobong asap yang lebih bersih sehingga kerja mesin dapat menjadi lebih optimal dan konsumsi bahan bakar pun dapat diminimalkan. Sedangkan emisi gas NOX dapat dikendalikan dengan penerapan teknologi selective noncatalytic reduction, yang mampu mengurangi emisi kadar nitrogen oksida (NO2) dalam gas buang sebanyak 75-98\%. Dalam laporan tahunannya perusahaan telah mengungkapkan ketentuan EN20 tentang NOx, Sox yang diperinci berdasarkan jenis dan berat.

Fokus utama Perusahaan yang terkait dengan pengelolaan limbah padat dan limbah cair (efluen) adalah memastikan bahwa limbah yang Perusahaan lepaskan ke lingkungan dari proses-proses penambangan dan produksi membawa dampak negatif yang minimal terhadap lingkungan juga masyarakat di sekitar wilayah operasi Perusahaan. Pendekatan Perusahaan dalam pengelolaan limbah secara bertanggung jawab juga dilandasi oleh prinsip 3R, yakni kurangi (reduce), pakai ulang (reuse), dan daur ulang (recycle). Sepanjang tahun 2011, Perusahaan sedapat mungkin meminimalisasi jumlah air limpahan dan air limbah yang dibuang ke badan air. Beberapa langkah yang diambil Perusahaan adalah pengukuran dan pemantauan kualitas air limpahan dan limbah cair, menggunakan beberapa parameter yang disesuaikan dengan baku mutu yang ditentukan oleh Pemerintah.

Air limbah yang dihasilkan Pusat Pencucian Bijih Timah di Unit Metalurgi Mentok diolah dan ditangani di fasilitas pengolahan air limbah milik Perusahaan, di mana teknologi yang digunakan adalah dengan mengendapkan material padat melalui sistem sirkulasi air tertutup. Dengan teknologi seperti ini, seluruh material padat yang terlarut akan mengendap, dan air limpahannya akan dimurnikan sehingga bersih dari unsur-unsur yang membahayakan, sesuai baku mutu yang ditentukan Pemerintah. Setelah seluruh langkah tersebut ditempuh, barulah hasil pengolahan air limbah yang aman ini dibuang ke laut. Perusahaan memeriksa kualitas air limbahnya setiap hari, dan satu kali setiap bulan, pengujian kualitas air limbah dilakukan oleh laboratorium independen yang telah memperoleh akreditasi dari Komisi Akreditasi Nasional. Hal yang berbeda ditemui di lokasi tambang terbuka Pemali. Di lokasi ini, sebagian air buangan dialirkan ke badan air, yaitu sungai di sekitar tambang, setelah melalui pengawasan ketat yang menjamin bahwa air tersebut tidak lagi mengandung unsur-unsur yang berbahaya bagi kesehatan dan tidak akan mengganggu ekosistem badan sungai. Perusahaan telah mengungkapkan ketentuan EN21 mengenai Jumlah buangan air menurut kualitas dan tujuan di tahun 2009, 2010 dan 2011. 
Berbagai jenis limbah padat dapat dihasilkan dari berbagai kegiatan operasional Perusahaan, yang terbagi dalam dua kategori. Pertama, limbah yang relatif tidak berbahaya atau berdampak negatif terhadap kesehatan manusia, seperti kertas, sampah, dan limbah domestik lainnya. Pengelolaan limbah kategori ini dilakukan berlandaskan prinsip daur ulang dan pakai ulang, baik oleh Perusahaan sendiri maupun oleh pihak-pihak lain. Kategori yang kedua adalah limbah yang tergolong dalam jenis barang berbahaya dan beracun (B3), termasuk limbah dengan kandungan unsur radioaktif. Pengelolaan limbah kategori ini dilandaskan pada prinsip kehati-hatian dalam penyimpanan, pemusnahan, dan juga pemanfaatannya. Jenis limbah padat yang ditangani secara khusus terdapat pada tabel 7 lampiran. Laporan tahunan 2011 memberikan penjelasan yang lebih rinci mengenai ketentuan EN22 dibanding laporan tahunan sebelumnya. Perusahaan mengatur ketat penggunaan bahan kimia, oli, dan bahan bakar untuk proses produksi dan penambangan. Pengaturan ini melingkupi kegiatan pengangkutan, pemindahan, maupun pemanfaatannya. Tujuannya adalah mencegah terjadinya tumpahan yang berpotensi merusak keanakeragaman hayati, mengganggu fungsi tanah lapisan atas, air, udara, dan juga kesehatan manusia. Sepanjang tahun 2009, 2010 dan 2011, langkah antisipatif yang dilakukan Perusahaan untuk mencegah hal tersebut terbukti berhasil: tidak ada insiden tumpahan bahan kimia, oli, dan bahan bakar minyak, dan tidak ada pengaduan apapun dari masyarakat terkait praktik pengelolaan limbah Perusahaan (Sesuai ketentuan EN23).

Limbah B3 dari Perusahaan ditampung di Tempat Penampungan Sementara Baturusa, untuk selanjutnya dimusnahkan menggunakan insinerator. Sebagian limbah B3 yang dihasilkan perusahaan diserahkan kepada pihak luar yang telah mendapatkan izin pengelolaan limbah dari Pemerintah untuk dikelola lebih lanjut. Beberapa langkah penanganan limbah B3 di tempat penampungan sementara adalah: memasang papan nama pada lokasi penampungan; melengkapinya dengan simbol dan peringatan tentang ancaman bahaya radiasi akibat paparan radioaktif; melaporkan hasil inventarisasi limbah yang digolongkan sebagai logam berbahaya dan radioaktif setiap tiga bulan sekali; dan melakukan pemeriksaan rutin yang melibatkan Badan Pengawasan Tenaga Nuklir.

Perusahaan mengungkapkan ketentuan EN24 mengenai limbah B3 untuk sepanjang tahun 2009, 2010 dan 2011.Untuk mengelola limbah yang dihasilkan dari kegiatan produksi, Perusahaan melakukannya secara internal atau menyerahkan pekerjaan tersebut kepada pihak ketiga yang telah mendapatkan lisensi pengelolaan limbah dari Perusahaan. Dengan demikian, pada tahun 2011 Perusahaan tidak mengekspor ataupun mengimpor limbah padat B3 atau limbah padat lainnya. Mengenai ketentuan EN 25, sistem sirkulasi air tertutup yang diimplementasikan di tahun 2011 dan tahuntahun sebelumnya pada tambang-tambang darat milik Perusahaan memastikan bahwa tidak ada air limpahan sisa penambangan yang dibuang atau dialirkan secara sengaja ke badan sungai di sekitarnya. Oleh karena itu, selama tahun 2009, 2010 dan 2011 Perusahaan tidak pernah menerima laporan ataupun mengidentifikasi adanya kerusakan ekosistem di badan air ataupun habitat di sekitarnya.

Sub-indikator Produk dan Jasa; pengungkapan EN26 dan 27 adalah sebagai berikut. Logam timah sebagai produk utama Perusahaan pada hakikatnya adalah material yang dapat didaur ulang dengan relatif mudah. Beberapa contoh penggunaan timah daur ulang dapat ditemukan dalam produkproduk elektronik dan kemasan. Selain itu, produk-produk timah Perusahaan telah memperoleh sertifikat jaminan kualitas produk dari Bursa Logam London, yakni LME BS EN 610:1996, dan dari ASTM International, yakni ASTM B 339-1995. Hal ini menegaskan tingginya kualitas produk-produk PT Timah (Persero) Tbk dan juga bahwa proses pengelolaan limbahnya telah optimal, sehingga dampak yang ditimbulkan terhadap lingkungan menjadi lebih sedikit. Hal ini tercermin secara nyata dari langkah-langkah yang diambil Perusahaan sepanjang tahun 2009, 2010 dan 2011 untuk memitigasi dampak-dampak lingkungan yang dihasilkannya. Langkah tersebut meliputi penanaman pohon, uji emisi cerobong, uji kualitas air laut, dan uji kualitas air. Pada tahun 2009, 2010 dan 2011 tidak ada produk Perusahaan yang ditarik atau dikumpulkan kembali dari publik untuk diolah, digunakan kembali, ataupun didaur ulang oleh Perusahaan sendiri. 
Sub-indikator Kepatuhan; untuk ketentuan EN28, Perusahaan selalu menjunjung tinggi dan berkomitmen penuh terhadap segala peraturan perundang-undangan maupun standar-standar lingkungan yang berlaku internasional. Oleh karena itu, sepanjang tahun 2009, 2010 dan 2011, Perusahaan tidak pernah menerima tuntutan ataupun pelanggaran terhadap ketentuan dan peraturan perundang-undangan di bidang lingkungan sehingga Perusahaan tidak pernah menerima sanksi untuk membayar denda.

Sub-indikator Pengangkutan/Transportasi (EN29); semua hasil penambangan di darat dan di laut didistribusikan ke unit peleburan menggunakan sejumlah alat transportasi, kemudian hasilnya dikirimkan ke gudanggudang Perusahaan atau ke Pelabuhan untuk diserahkan ke konsumen. Selama proses pengangkutan, timbul emisi gas dari truk dan kapal pengangkut yang digunakan oleh Perusahaan. Untuk memantau kinerja program mitigasi emisinya, Perusahaan melakukan pemantauan kualitas udara secara berkala di sejumlah tempat yang mencakup rute pengangkutan rutinnya. Hasil pemantauan ini menunjukkan bahwa kandungan partikel debu dan kualitas gas buang kendaraan yang digunakan Perusahaan berada di dalam kriteria baku mutu yang ditetapkan. Selain itu, efektivitas perjalanan dinas dan pengangkutan karyawan dari dan ke kapal dimaksimalkan oleh Perusahaan, demi mengurangi akibat buruk dari emisi gas. Perusahaan juga menjalankan kebijakan untuk menyewa hanya perusahaan pengangkutan dan pelayaran yang reputasi dan kredibilitasnya prima.

Sub-indikator Menyeluruh; untuk membiayai berbagai upaya pengelolaan lingkungan hidup di seluruh wilayah operasionalnya, Perusahaan mengeluarkan dana senilai Rp 5.674.614.500 sepanjang tahun 2011 seperti terlihat pada tabel 8 lampiran. Pada tahun 2011, PT Timah juga telah mengeluarkan dana senilai Rp 9.894.898.900 untuk melaksanakan upaya reklamasi, yang mencakup tahapan perataan dan penanaman, di sejumlah lahan pascatambang Perusahaan. Sementara itu, jumlah dana yang digunakan untuk program CSR bidang pelestarian alam di tahun 2011 mencapai Rp 69.095.000. Pengungkapan EN30 yang terinci mengenai jumlah pengeluaran untuk proteksi dan investasi lingkungan menurut jenis hanya ada di laporan tahunan 2011.

\section{SIMPULAN}

Berdasarkan pembahasan tentang akuntansi lingkungan, pemeliharaan lingkungan, serta citra perusahaan didapatkan hasil seperti pada tabel 1 berikut ini.

Tabel 1 Temuan hasil evaluasi pengungkapan akuntansi lingkungan berdasarkan GRI 3.1

\begin{tabular}{ll}
\multicolumn{1}{c}{ Indikator } & \\
\hline EN5 & Tidak disebutkan jumlah moneter penghematan energi \\
EN6 & Yang diungkapkan baru rencana sedangkan yang diminta adalah realisasi inisiatifnya \\
EN7 & Belum disertai dengan angka riil pengurangan konsumsi energi yang dicapai tahun 2009, 2010 \\
& dan 2011 \\
EN10 & Tidak mengungkapkan persentase dan total volume air yang digunakan kembali dan didaur \\
& ulang sepanjang tahun 2009, 2010 dan 2011 \\
EN11 & Tidak mengungkapkan secara detil ketentuan EN11 di tahun 2011 \\
EN16 dan EN 17 & Tidak diungkapkan rincian jumlah emisi gas rumah kaca langsung maupun minor berdasarkan \\
& berat untuk tahun 2009, 2010, 2011 \\
EN18 & Tidak diungkapkan inisiatif untuk mengurangi remisi gas rumah kaca dan pencapaiannya di \\
tahun 2009, 2010 dan 2011. & Tidak mengungkapkan ketentuan mengenai Emisi bahan kimia yang merusak lapisan ozon, \\
EN19 & diperinci berdasarkan berat untuk tahun 2009, 2010 dan 2011. \\
&
\end{tabular}

Sumber: Hasil pengolahan data 
Dari temuan diatas dapat disimpulkan sebagai berikut. Peranan akuntansi lingkungan diperlukan dalam setiap tahap yang berada di supply chain perusahaan. Namun, perusahaan belum menerapkan akuntansi lingkungan secara penuh. Secara garis besar, cukup banyak data perusahaan yang dapat digunakan untuk menunjang penerapan akuntansi lingkungan. Tidak terlihat sistem informasi yang mengintegrasikan data lingkungan dengan data ekonomi. Perusahaan belum mengonversikan satuan unit menjadi satuan moneter atas efisiensi biaya yang diperoleh dari pengolahan limbah dan energi alternatif. PT Timah menyiapkan anggaran pada tahun 2009, sekitar Rp 26,6 miliar untuk pelaksanaan program CSR yang merupakan dana yang wajib dicadangkan bagi perusahaan yang memanfaatkan sumber daya alam (SDA). Dari segi pemberdayaan lingkungan dan bentuk pertanggungjawaban perusahaan untuk memulihkan fungsi lahan yang telah digunakan untuk pertambangan sebelumnya. PT Timah telah mengambil langkah yang cukup baik untuk menjaga kelestarian lingkungan pasca pertambangan. Sepanjang tahun 2010-2012, Perusahaan merencanakan reklamasi seluas 2.000 ha per tahun selama 2 tahun mendatang. Berdasarkan atas berbagai evaluasi dalam perencanaan, dan pelaporan keuangan, dan bentuk realisasi kerja sama bina lingkungan PT Timah dapatlah disimpulkan bahwa PT Timah adalah perusahaan yang cukup mempertimbangkan keamanan lingkungan secara optimal. Walaupun secara garis besar bahwa Provinsi Bangka Belitung sudah dalam kondisi kritis terkait dengan kondisi kerusakan hutan, pencemaran air, atau banyaknya alih profesi dari mayoritas nelayan menjadi penambang inkonvensional (TI)

\section{DAFTAR PUSTAKA}

Akuntan Indonesia, mitra dalam perubahan. (2007, November). Audit Lingkungan Suatu Keharusan?, Edisi No.3. Dipetik April 17, 2012, dari www.iaiglobal.or.id/data/referensi/ai_edisi_03.pdf

Cohen, J., Holder-Webb, L., Nath, L., \& Wood, D (2011). Corporate Reporting of Non-Financial Leading Indicators of Economic Performance and Sustainability.

Environmental Management System. (2011, January 1). Dipetik Maret 19, 2012, dari US EPA: http://www.epa.gov/ems/

GRI. N.d. www.globalreporting.co.id. Diakses tanggal 5 Januari 2012.

Halim, A., \& Irawan, S. (1998). Perspektif Akuntansi Lingkungan. Jurnal Ekonomi dan Bisnis.

Ikatan Akuntan Indonesia. 2009. Standar akuntansi keuangan, Jakarta: Salemba Empat.

INTOSAI WGEA. (2010). Environmental Accounting: Current Status and Options for SAIs.

Laporan Tahunan PT Timah (Persero) Tbk tahun 2009

Laporan Tahunan PT Timah (Persero) Tbk tahun 2010

Laporan Tahunan PT Timah (Persero) Tbk tahun 2011

Mihardika, D. (2012). Kajian Atas Akuntansi Pertambangan Umum di Indonesia Berdasarkan Rekaan Penerapan IFRS 6 / PSAK 64 (2011) Dan PSAK 33 (Revisi 2011): Studi Kasus Pada PT. Antam (Persero) Tbk. Thesis S1 Tidak Dipublikasikan, Universitas Bina Nusantara, Jakarta.

Sahasrakirana, G.W. (2012). Evaluasi Peran Akuntansi Lingkungan Untuk Mendukung Keputusan Manajemen Lingkungan Pada PT Sahabat Mewah Dan Makmur (Anj Agri Belitung) Dalam Rangka Mencapai Sustainability Perusahaan. Thesis S1 Tidak Dipublikasikan, Universitas Bina Nusantara, Jakarta. 
Santy (2012). Analisis Pelaporan Corporate Social Responsibility pada Perusahaan - perusahaan Sektor Pertambangan Batubara di Indonesia dan Australia yang Tercatat di Bursa Saham masing-masing Negara. Thesis S1 Tidak Dipublikasikan, Universitas Bina Nusantara, Jakarta.

Sugiyono. 2008. Metode Penelitian Kuantitatif, Kualitatif dan $R \&$ D, Bandung: Alfabeta.

The Ministry of Environment, J. (2005). Environmental Accounting Guidelines.

Undang-Undang Republik Indonesia Nomor 40 Tahun 2007 tentang Perseroan Terbatas. 


\section{LAMPIRAN}

Tabel 2 Daftar Indikator Pengungkapan Kinerja Lingkungan Menurut GRI 3.1

\begin{tabular}{|c|c|c|c|}
\hline Indikator & Sub-indikator & Kode & Keterangan \\
\hline \multirow{30}{*}{$\begin{array}{l}\text { Kinerja } \\
\text { Lingkungan }\end{array}$} & Material & EN1 & Penggunaan bahan; diperinci berdasarkan berat atau volume. \\
\hline & & EN2 & Presentase penggunaan bahan daur ulang \\
\hline & Energi & EN3 & Penggunaan energi langsung dari sumberdaya energi primer. \\
\hline & & EN4 & Pemakaian energi tidak langsung berdasarkan sumber primer. \\
\hline & & EN5 & Penghematan energi melalui konversi dan peningkatan efisiensi. \\
\hline & & EN6 & $\begin{array}{l}\text { Inisiatif untuk mendapatkan produk dan jasa berbasis energi efisien atau energi } \\
\text { yang dapat diperbaharui, serta pengurangan persyaratan kebutuhan energi } \\
\text { sebagai akibat dari inisiatif tersebut. }\end{array}$ \\
\hline & & EN7 & $\begin{array}{l}\text { Inisiatif untuk mengurangi konsumsi energi tidak langsung dan pengurangan } \\
\text { yang dicapai. }\end{array}$ \\
\hline & Air & EN8 & Total pengambilan air per sumber. \\
\hline & & EN9 & Sumber air yang terpengaruh secara signifikan akibat pengambilan air. \\
\hline & & EN10 & Presentase dan total volume air yang digunakan kembali dan didaur ulang. \\
\hline & $\begin{array}{l}\text { Biodiversitas } \\
\text { (Keanekaragaman } \\
\text { Hayati) }\end{array}$ & EN11 & $\begin{array}{l}\text { Lokasi dan ukuran tanah yang dimiliki, disewa, dikelola oleh organisasi pelapor } \\
\text { yang berlokasi didalam, atau yang berdekatan dengan daerah yang diproteksi } \\
\text { (dilindungi) atau daerah-daerah yang memiliki nilai keanekaragaman hayati di } \\
\text { luar daerah yang diproteksi. }\end{array}$ \\
\hline & & EN12 & $\begin{array}{l}\text { Uraian atas berbagai dampak signifikan yang diakibatkan oleh aktivitas, } \\
\text { produk, dan jasa organisasi pelapor terhadap keanekaragaman hayati di daerah } \\
\text { yang diproteksi (dilindungi) dan di daerah yang memiliki keanekaragaman } \\
\text { hayati bernilai tinggi di lur daerah yang diproteksi (dilindungi) }\end{array}$ \\
\hline & & EN13 & Perlindungan dan pemulihan habitat. \\
\hline & & EN14 & $\begin{array}{l}\text { Strategi, tindakan, dan rencana mendatang untuk mengelola dampak terhadap } \\
\text { keanekaragaman hayati. }\end{array}$ \\
\hline & & EN15 & $\begin{array}{l}\text { Jumlah spesies berdasarkan tingkat resiko kepunahan yang masuk dalam Daftar } \\
\text { Merah IUCN (IUCN Red List Species) dan yang masuk dalam daftar konservasi } \\
\text { nasional dengan habitat di daerah-daerah yang terkena dampak operasi. }\end{array}$ \\
\hline & $\begin{array}{l}\text { Emisi, Efluen dan } \\
\text { Limbah }\end{array}$ & EN16 & $\begin{array}{l}\text { Jumlah emisi gas rumah kaca yang sifatnya langsung maupun tidak langsung } \\
\text { dirinci berdasarkan berat. }\end{array}$ \\
\hline & & EN17 & Emisi gas rumah kaca tidak langsung lainnya diperinci berdasarkan berat. \\
\hline & & EN18 & Inisiatif untuk mengurangi remisi gas rumah kaca dan pencapaiannya. \\
\hline & & EN19 & $\begin{array}{l}\text { Emisi bahan kimi yang merusak lapisan ozon (ozone-depletig substances/ODS) } \\
\text { diperinci berdasarkan berat. }\end{array}$ \\
\hline & & EN20 & $\begin{array}{l}\text { NOx, Sox dan emisi udara signifikan lainnya yang diperinci berdasarkan jenis } \\
\text { dan berat. }\end{array}$ \\
\hline & & EN21 & Jumlah buangan air menurut kualitas dan tujuan. \\
\hline & & EN22 & Jumlah berat limbah menurut jenis dan metode pembuangan. \\
\hline & & EN23 & Jumlah dan volume tumpahan yang signifikan. \\
\hline & & EN24 & $\begin{array}{l}\text { Berat limbah yang diangkut, diimpor, diekspor, atau diolah yang diangap } \\
\text { berbahaya menurut Lampiran Konvensi Basel I, II. III, dan VIII, dan presentase } \\
\text { limbah yang diangkut secara internasional. }\end{array}$ \\
\hline & & EN25 & $\begin{array}{l}\text { Identitas, ukuran, status proteksi dan nilai keanekaragaman hayati badan air } \\
\text { seta habitat yang secara signifikan dipengaruhi oleh pembuangan dan limpasan } \\
\text { air organisasi pelapor. }\end{array}$ \\
\hline & Produk dan Jasa & EN26 & $\begin{array}{l}\text { Inisiatif untuk mengurangi dampak lingkungan produk dan jasa dan sejauh } \\
\text { mana dampak pengurangan tersebut. }\end{array}$ \\
\hline & & EN27 & Presentase produk terjual dan bahan kemasannya yang ditarik menurut kategori. \\
\hline & Kepatuhan & EN28 & $\begin{array}{l}\text { Nilai moneter denda yang signifikan dan jumlah sanksi nonmoneter atas } \\
\text { pelanggaran terhadap hukum dan regulasi lingkungan. }\end{array}$ \\
\hline & $\begin{array}{l}\text { Pengangkutan/ } \\
\text { Transportasi }\end{array}$ & EN29 & $\begin{array}{l}\text { Dampak lingkungan yang signifikan akibat pemindahan produk dan barang- } \\
\text { barang lain serta material yang digunakan untuk operasi perusahaan, dan tenaga } \\
\text { kerja yang memindahkan. }\end{array}$ \\
\hline & Menyeluruh & EN30 & Jumlah pengeluaran untuk proteksi dan investasi lingkungan menurut jenis. \\
\hline
\end{tabular}

Sumber: GRI 3.1 
Tabel 3 Penggunaan Material untuk Peleburan Timah

Semua angka dinyatakan dalam ribuan kilogram (metrik ton)

\begin{tabular}{|c|c|c|c|c|c|c|c|c|c|c|}
\hline \multirow{3}{*}{ Jenis Material } & \multicolumn{2}{|c|}{2011} & \multirow{3}{*}{$\begin{array}{l}\text { Total } \\
\text { (ton) }\end{array}$} & \multicolumn{3}{|c|}{2010} & \multicolumn{3}{|c|}{2009} & \multirow{3}{*}{ Keterangan } \\
\hline & \multicolumn{2}{|c|}{ Fasilitas Peleburan } & & \multicolumn{2}{|c|}{ Fasilitas Peleburan } & \multirow{2}{*}{$\begin{array}{l}\text { Total } \\
\text { (ton) }\end{array}$} & \multicolumn{2}{|c|}{ Fasilitas Peleburan } & \multirow{2}{*}{$\begin{array}{l}\text { Total } \\
\text { (ton) }\end{array}$} & \\
\hline & Mentok & Kundur & & Mentok & Kundur & & Mentok & Kundur & & \\
\hline Bijih timah & 45.183 & 6.274 & 51.457 & 44,451 & 10,394 & 54,845 & 49,767 & 7,256 & 57,023 & Bahan baku \\
\hline Terak I & 23.097 & 2.548 & 25.645 & 36,398 & 5,613 & 42,011 & 50,369 & 951 & 51,320 & $\begin{array}{l}\text { Bahan baku daur } \\
\text { ulang }\end{array}$ \\
\hline Debu & 2.672 & 634 & 3.306 & 2,754 & 491 & 3,245 & 3,186 & 329 & 3,515 & $\begin{array}{l}\text { Bahan baku daur } \\
\text { ulang }\end{array}$ \\
\hline Dross & 8.661 & 3.412 & 12.073 & 9,634 & 2,982 & 12,616 & 12,702 & 1,813 & 14,515 & $\begin{array}{l}\text { Bahan baku daur } \\
\text { ulang }\end{array}$ \\
\hline Hardhead & 10.287 & 1.128 & 11.415 & 11,356 & 926 & 12,282 & 7,656 & 146 & 7,802 & $\begin{array}{l}\text { Bahan baku daur } \\
\text { ulang }\end{array}$ \\
\hline Timah besi & 2.672 & 233 & 2.905 & 1,813 & 118 & 1,931 & 752 & 364 & 1,116 & $\begin{array}{l}\text { Bahan baku daur } \\
\text { ulang }\end{array}$ \\
\hline $\begin{array}{l}\text { Batubara } \\
\text { antrasit }\end{array}$ & 12.661 & 3.157 & 15.818 & 14,735 & 2,614 & 17,349 & 17,122 & 1,548 & 18,670 & Bahan pembantu \\
\hline Fluks & 2.191 & 726 & 2.917 & 2,965 & - & 2,965 & 4,156 & 360 & 4,516 & Bahan pembantu \\
\hline $\begin{array}{l}\text { Total Bahan } \\
\text { Baku }\end{array}$ & 92.572 & 14.229 & 106.801 & 106,406 & 20,524 & 126,930 & 124,432 & 10,858 & 135,290 & \\
\hline Total Material & 107.424 & 18.112 & 125.536 & 124,106 & 23,138 & 147,244 & 145,710 & 12,766 & 158,476 & \\
\hline
\end{tabular}

Sumber: Hasil pengolahan data.

Tabel 4 Penggunaan Energi

\begin{tabular}{|c|c|c|c|c|c|c|c|c|}
\hline \multirow{2}{*}{$\begin{array}{l}\text { Sumber } \\
\text { Primer }\end{array}$} & \multirow[t]{2}{*}{ Satuan } & \multirow{2}{*}{$\begin{array}{l}\text { Kandungan } \\
\text { Energi }\end{array}$} & \multicolumn{2}{|c|}{2011} & \multicolumn{2}{|c|}{2010} & \multicolumn{2}{|c|}{2009} \\
\hline & & & Jumlah (GJ) & Total Energi & Jumlah (GJ) & Total Energi & Jumlah (GJ) & Total Energi \\
\hline $\begin{array}{l}\text { Batubara } \\
\text { antrasit }\end{array}$ & ton & $28,5 \mathrm{GJ} / \mathrm{ton}$ & 15.818 & 450.813 & 20.000 & 570.000 & 14,001 & 399,029 \\
\hline $\begin{array}{l}\text { Solar } \\
\text { industri } \\
\text { (HSD) }\end{array}$ & liter & 0,0364 GJ/liter & 54.554 .563 & 1.985 .786 & 58.694 .625 & 2.136 .484 & $53,340,407$ & $1,941,591$ \\
\hline $\begin{array}{l}\text { Minyak } \\
\text { bakar }\end{array}$ & liter & 0,038 GJ/liter & 13.351 .575 & 507.360 & 14.775 .447 & 561.467 & $18,273,481$ & 694,342 \\
\hline TOTAL & & & 67.921 .956 & 2.943 .959 & & 3.267 .951 & & $3,034,962$ \\
\hline
\end{tabular}

Sumber: Hasil pengolahan data.

Tabel 5 Inland IUP Areas

\begin{tabular}{lllllll}
\multicolumn{1}{c}{ Type } & Unit & Bangka & Belitung & $\begin{array}{c}\text { Total in } \\
\mathbf{2 0 1 0}\end{array}$ & $\begin{array}{c}\text { Percentage } \\
\text { of Total }\end{array}$ & $\begin{array}{c}\text { Total in } \\
\mathbf{2 0 0 9}\end{array}$ \\
\hline Productive Forest & hectare & 71,671 & 8,155 & 79,826 & $79,39 \%$ & 111,679 \\
Protected Forest & hectare & 16,783 & 3,935 & 20,718 & $20,61 \%$ & 27,812 \\
TOTAL & hectare & 88,454 & 12,090 & 100,544 & $100 \%$ & 139,491 \\
\hline
\end{tabular}

Sumber: Hasil pengolahan data.

Tabel 6 Species dalam Red List IUCN

\begin{tabular}{lc}
\hline \multicolumn{1}{c}{ Nama Spesies } & Kategori Konservasi IUCN \\
\hline Terumbu karang & Membahayakan \\
Simping & Membahayakan \\
Cacing wak-wak & Membahayakan \\
Siput gong-gong & Membahayakan \\
Udang putih (Panaeus merguinensis) & Nyaris terancam \\
Udang windu (Panaeus monodon) & Nyaris terancam \\
Kepiting hitam (Scyla serrata) & Mudah diserang \\
\hline
\end{tabular}

Sumber: Hasil pengolahan data. 
Tabel 7 Jenis Limbah Padat dengan Penanganan Khusus

\begin{tabular}{cc}
\hline $\begin{array}{c}\text { Mengandung Logam } \\
\text { Berbahaya }\end{array}$ & Mengandung Unsur Radioaktif \\
\hline ilmenite & thorium \\
monazite & uranium \\
xenotime & \\
zircon & \\
\hline
\end{tabular}

Sumber: Hasil pengolahan data.

Tabel 8 Biaya Pengelolaan Lingkungan

\begin{tabular}{llll}
\hline No & \multicolumn{1}{c}{ Jenis Kegiatan } & \multicolumn{1}{c}{ Jumlah } \\
\hline 1 & Biaya Pemantauan Lingkungan Hidup & Rp 481.438.000,00 \\
2 & Biaya Analisis Sampel & Rp 607.462.000,00 \\
3 & Inspeksi Internal Objek Kerja & Rp 205.757.000,00 \\
4 & Pencegahan Pencemaran Lingkungan & Rp 27.500.000,00 & Rp 1.563.470.000,00 \\
5 & Perawatan Peralatan Pemantauan Lingkungan & Rp 241.313.000,00 & \\
& TOTAL 1 & Rp 102.305.000,00 & \\
6 & Audit Lingkungan (Eksternal) & Rp 2.114.962.500,00 & Rp 15.136.000,00 4.111.144.500,00 \\
7 & Perizinan terkait Pengelolaan Lingkungan & Rp 1.536.900.000,00 & Rp 5.674.614.500,00 \\
8 & Pelaporan dan Dokumentasi & Rp 341.841.000,00 \\
9 & Jasa Konsultasi & &
\end{tabular}

